\title{
School Location and Gender as Predictors of Students' Performance in WASSCE Multiple Choice Test in Biology
}

\author{
ADEKUNLE T. OLUTOLA \\ ORCID No. 0000-0002-5958-793X \\ olutolatola@gmail.com \\ Department of Educational Foundations, \\ Faculty of Education, Federal University Dutsinma, \\ P.M.B 5001, Katsina State, Nigeria
}

\begin{abstract}
This study investigated school location and gender as predictors of students' performance in West African Senior School Certificate Examination (WASSCE) multiple choice test in biology. The researcher adopted survey research design for the study. Sample for the study consisted of 1450 Secondary School Three (SSIII) students drawn from 20 randomly selected senior secondary schools in Ekiti State, Nigeria. The instrument used for the study was 2008 WASSCE multiplechoice Biology test paper. Findings from the study showed that significant different existed between students' performance in WASSCE multiple choice test in biology based on school location $(\mathrm{df}=1448, \mathrm{t}=6.84, \mathrm{P}<0.05)$; gender $(\mathrm{df}=1448, \mathrm{t}=8.89, \mathrm{P}<0.05)$, and school type $(\mathrm{df}=2,1447,1449 ; \mathrm{F}=211.68$, $\mathrm{P}<0.05)$. Based on these findings, the researcher recommended that secondary school administrators and Biology teachers should encourage male and female Biology students' to participate actively during the weekly lessons to improve their performance in WASSCE Biology Examination.
\end{abstract}

Keywords: Biology, multiple choice test, school location, students' performance, WASSCE

\section{INTRODUCTION}

Examinations occupy a unique and important position, as a measure of quality within the educational system in Nigeria and the whole world in general. Examination refers to an act of measuring or an exercise of a series of tasks 
designed to determine the achievement of a learner. It consists of series of tests or questions or items designed to measure the knowledge, skills and attainment of the learners as defined by the goals of the syllabus or subject concerned (Good, 1973; Hornby, $2000 \&$ Somoye, 2002). The role of examination is very vital in evaluating students in the school setting.

West African Senior School Certificate Examination (WASSCE) is a Senior School Certificate Examination (SSCE) conducted by West African Examination Council. West African Examinations Council (WAEC) is one of the examination bodies authorized by the Nigerian law to conduct the Senior Secondary School Certificate Examination (SSSCE), General Certificate Examination (GCE) and other exams.

The West African Examinations Council was established in 1952 following the acceptance of the Jeffery Report by the then colonial Government(s) established in (1952) by five West African Government namely Ghana, Liberia, Gambia, Nigeria and Sierra Leone who passed appropriate ordinances in their Legislative Assemblies in 1951 in collaboration with and in succession to, the Cambridge School Certificate Syndicate. It has his headquarters in Accra, Ghana while the Nigeria headquarters is in Yaba, Lagos. The ordinances charged the Council with the responsibility of determining the examinations required in the public interest in West Africa, and empowered it to conduct such examinations and award appropriate certificates (WAEC Diary, 2004 \& WAEC, 2007).

West African Examinations Council (WAEC) organizes the Senior Secondary Certificate Examination (SSCE), which are essentially for certification. The West African Examinations Council (WAEC) as an international organization has undoubtedly played a unique role in West Africa. The examinations conducted by WAEC are public examinations. Public examinations are examinations that are conducted by recognized examining bodies such as WAEC. Obioma and Salawu (2007), viewed public examination as external school examinations open to the general public and conducted by certain bodies using test that have appropriate psychometric properties.

The common form of test used by statutory examining bodies like WAEC for external assessment is of the objective, essay and practical variants. However, Multiple choice tests are becoming more and more popular particularly in public examinations. Multiple choice tests are not only popular in external examinations; they also play a crucial role in assessment processes in the school system. This may be because they ease and objectifies the assessment procedures (Olutola, 2015). Multiple choice tests are widely acclaimed as most reliable because of consistency 
in scoring the test as well as its fairness to all students (Osunde, 2009). Multiple choice tests discourage the learner's tendency to anticipate likely questions but encourage them to cover the whole contents taught in their preparations. They are also useful in assessing learners' mastery of specific- facts, concepts, terms, laws and principles (Lawal, 2001 \& Kolawole, 2005).

According to Kolawole (2005), multiple choice tests require students to select the answer from a number of possible alternatives. Multiple choice items give the fairest opportunity to testees to prove their competence and testers to prove their integrity. Its objectivity is both in terms of development and in terms of scoring as items cover wider curriculum contents and objectives of instruction. It is adjudged as having good validity since it has the tendency to cover all aspects of learning content (Alonge, $2003 \&$ Lawal, 2001).

The West African Examination Council (WAEC) used multiple choice tests in their biology questions. Biology views human beings in their present, past and future lives (Ahmed, 2004). Biology is one of the science subjects that deal with life that is plants and animals or the study of living things and their vital processes. It is one of the core subjects, taught at the senior secondary school level. According to Parker (1992), Biology embraces those principles of widest application to the origin, growth and development, structure, function, evolution and distribution of plants and animals or living organisms' e.g. bacteria, fungi, and so on. Biology helps students to know more about plants, animals; show they grow and develop their breeding system and disease conditions.

Moreover, Biology as the science of life enables the individuals to understand themselves, the parts and functions of their bodies. In addition, Biology provides education for leisure time, in form of hobbies such as insect collection, bird watching and so on (Olatunji, 2004). In Nigeria, gender bias in science subjects including Biology is still prevalent and persisted. According to Igwe (2003), gender issue is an important factor in educational setting and could be a hindrance to high achievement of learners in science subjects. The role of gender in academic performance of students in the school subjects especially in Biology cannot be overstated. Gender issues have been linked with performance of students in academic tasks in several studies but without any definite conclusion. Spence (2004) found no significant influence of gender on the achievement of college students in mathematics when they were exposed to mathematics courseware in online and traditional learning environment.

Some studies revealed that male students perform better than the females in physics, chemistry and Biology (Danmole, 1998; Novak \& Mosunda, 
1991). Yusuf, and Afolabi, (2010) investigated the effects of computer-assisted instruction (CAI) on secondary school students' performance in Biology. The influence of gender on performance of students exposed to CAI in individualized or co-operative learning settings package was examined.

In view of the above, this study investigated school location and gender as predictors of students' performance in West African Senior School Certificate Examination (WASSCE) multiple choice test in biology.

\section{FRAMEWORK}

Biology is one of the natural sciences offered by secondary school students in Nigeria and the most popular science subject students registered for during their WASSC examination. Despite, the importance and popularity of Biology among Nigerian students, performance at senior secondary school level had been poor and results of research studies revealed the poor performance of students in Biology. This student's poor performance in Biology poses a great challenge to all the stakeholders in education sector.

This study examined the influence of school location, school type and gender on students' performance in West African Senior School Certificate Examination (WASSCE) multiple choice test in biology. The framework/ plan of the study is presented below:

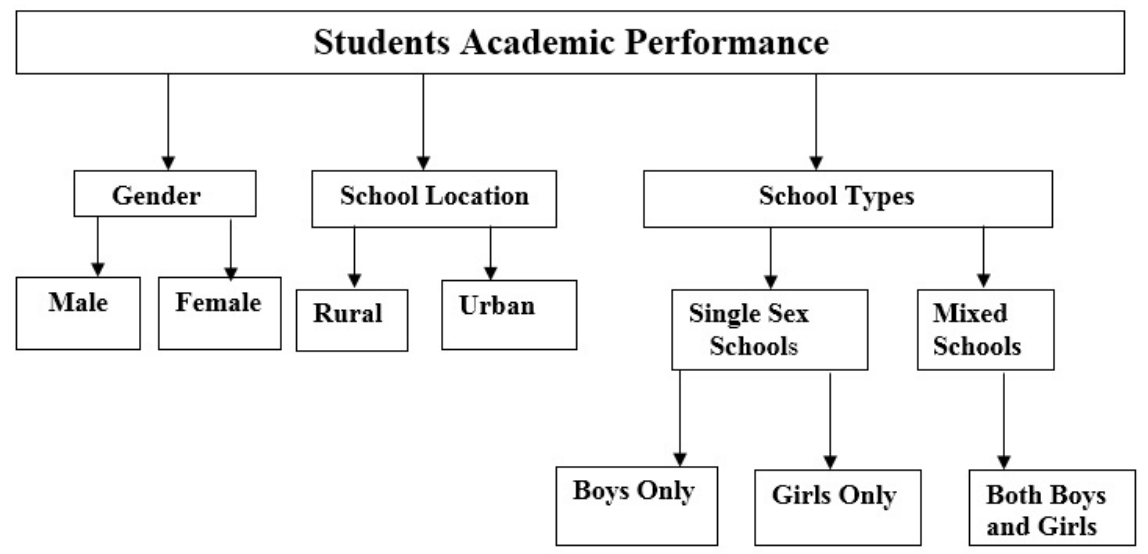

Figure 1. Conceptual Framework on How School Location, School Type and Gender Influence Students' Performance in Biology 


\section{Gender and Student Performance}

Gender is an important variable in the school system. Gender means both the male and female. Spence (2004) found no significant influence of gender on the achievement of college students in mathematics when they were exposed to mathematics courseware in online and traditional learning environment. Some studies revealed that male students perform better than the females in physics, chemistry and Biology (Danmole, 1998; Novak \& Mosunda, 1991). Aremu (1999) reported that boys are better than girls in Mathematics and other science subjects. Okwo and Otunba (2007) reported that boys performed better than girls in physics essay test.

\section{School Location and Students Performance}

School location means a particular area where a school is located. It can be rural area or urban area. The effect of school location on students' performance cannot be overemphasized. Akpan (2008) indicated that schools in urban areas have electricity, portable water supply, adequate teachers, more learning facilities and infrastructures. This may influence students' performance in the school. Onah (2011) and Owoeye (2002) noted that students in urban areas achieved more than students in the rural areas in science subjects. In addition, highly qualified teachers prefer to serve in urban schools rather than the schools in rural areas, that is the reason will find qualified teachers in urban schools than rural schools. Bosede (2010) stated that sex (gender) and school location influences students' academic achievement.

\section{School Types and Students Performance}

School type in this study means composition of the students in terms of gender in a particular school such as single sex school (boys only and girls' only schools) while mixed sex schools or coeducational schools comprises of both boys and girls. Lee, Marks and Byrd (1994) noted that in coeducational classrooms, boys receive the majority of teachers' attention, particularly in math and science. Interviewing and observing students in single-sex math classrooms in American secondary schools, Streitmatter (2002) found that the girls in a single-sex classroom had the sense of ownership of their class, while the same girls did not feel the sense of ownership in coeducational classrooms.

Females also benefit from single-sex environments. Sexual harassment is an unfortunate problem in coeducational environments (Guarisco, 2010). While the risk is still present in single-sex schools, some feel that the single-sex 
environment provides a safer environment for female students. Lee and Marks (1990), it was found that for males, Mathematics Scholastic Aptitude Test (SAT) scores were higher among those attending single-sex schools; while, for females, mathematics SAT scores were higher for those attending coeducational schools. In coeducational context, boys tend to monopolize their teachers attention, particularly in physics (Taber, 1992) and mathematics classes (Leder, 1990; Lee, Marks \& Byrd, 1994).

WAEC (2001) annual report showed that there was no year between 1995 and 2001 when up to $35 \%$ of candidates that sat for the SSCE Biology made a minimum of credit pass. In addition, Chief Examiners reports from 2001 to 2007 showed that students' performance in Biology was very poor. Moreover, the table below shows the performance of students' failure rate from 2010-2012.

Table 1. Percentage (\%) of Students Failure Rate in Some Science Subjects in WASSCE from (2010-2012)

\begin{tabular}{|l|l|l|l|l|l|}
\hline Subject & $\begin{array}{l}\text { \% of Failure } \\
2010\end{array}$ & $\begin{array}{l}\text { \% of Failure } \\
2011\end{array}$ & $\begin{array}{l}\text { \% of Failure } \\
2012\end{array}$ & $\begin{array}{l}\text { Average } \\
\text { Failure }\end{array}$ & Rank \\
\hline Biology & 22.86 & 29.34 & 33.77 & 28.66 & 1 \\
\hline Mathematics & 27.20 & 27.95 & 18.01 & 24.39 & 2 \\
\hline Chemistry & 21.08 & 22.82 & 23.65 & 22.52 & 3 \\
\hline English & 31.02 & 18.22 & 16.44 & 21.89 & 4 \\
\hline Physics & 18.27 & 11.76 & 09.20 & 13.8 & 5 \\
\hline
\end{tabular}

Source: WAEC, 2012

Table 1 shows the percentage failure rate of students SAT for WAEC science subjects between 2010 -2012. Students' percentage failure rate in Biology is higher than other science subjects. The performance of students in Senior Secondary Sciences in Nigeria has remained an issue of concern to all stakeholders (Ajagun, 2000). Teachers attitude and students lack of interest have been reported to be a major factors responsible for students perceived difficulty in science subjects including Biology (Oni, 2006 \& Unoroh, 2004). The causes and factors for the students' poor performance in Biology has been the focus of researchers.

Therefore, there is need for researchers to investigate variables that may influence students' performance in senior school certificate multiple choice test in Biology. Based on this, the study investigated school location and gender as 
predictors of students' performance in West African Senior School Certificate Examination (WASSCE) multiple choice test in biology.

\section{OBJECTIVES OF THE STUDY}

The study investigated school location and gender as predictors of students' performance in West African Senior School Certificate Examination (WASSCE) multiple choice test in biology. Specifically, the study determined the significant differences in the school location (rural and urban), gender (male and female) and school types (Boys Only, Girls Only and Mixed schools) on students' performance in West African Senior Secondary School Certificate Examination (WASSCE) multiple choice Biology test in Ekiti State, Nigeria.

\section{Research Hypotheses}

The researcher formulated three research hypotheses for the study.

Ho1: There is no significant difference in the students' performance in WASSCE multiple choice Biology test based on school location (rural and urban).

Ho2: There is no significant difference in the students' performance in WASSCE multiple choice Biology test on the basis of gender.

Ho3: There is no significant difference in the students' performance in WASSCE multiple choice Biology test on the basis of school type.

\section{METHODOLOGY}

The researcher adopted a descriptive survey research design because the data were collected through the test and no variable was manipulated during the conduct of the study. The population for this study consists of all senior secondary school students in Ekiti State. Ekiti State is one of the thirty-six states in Nigeria. The state has a largely agrarian economy and most communities engage in growing cash and food crops in commercial quantities.

The target population for this study consists of senior secondary school three (SS3) students in Ekiti State, Nigeria. Stratified random sampling technique was adopted for the study. The schools were stratified along three Senatorial Districts in Ekiti State namely: Ekiti Central, Ekiti North and Ekiti South senatorial districts. Thus, the research selected twenty senior (20) senior secondary schools 
(SS 3) from the three senatorial districts listed above. One thousand four hundred and fifty (1450) students were randomly selected to participate in the study. The instrument for this study was 2008 WASSCE multiple-choice Biology paper. This instrument was adopted for the study and it was a standardized test used by this examination body in Nigeria and some of the West African countries. This instrument was considered accurate and reliable by the public examination body. For data analysis of the study, t-test was used to analyse hypotheses one (1) and two (2) while Analysis of Variance (ANOVA) was used to analyse hypothesis three (3).

\section{RESULTS AND DISCUSSION}

Hypothesis 1. There is no significant difference in the students' performance in WASSCE multiple-choice Biology test based on school location (rural and urban).

The t-test analysis was used to determine students' performance in WASSCE multiple-choice Biology test based on school location (rural and urban) from the sampled schools.

Table 2. T-test Summary of Rural and Urban Students' Performance in WASSCE Multiple Choice Biology Test

\begin{tabular}{lllllcc}
\hline Variable & N & X & SD & DF & Cal. t-value & Sig of t-value \\
Urban & 979 & 23.73 & 14.42 & & & \\
Rural & 471 & 18.30 & 8.30 & & 6.84 & $.000(\mathrm{~S})$ \\
\hline
\end{tabular}

Table 2 indicates that calculated t-value of 6.84 which is significant at 0.05 alpha level. As revealed in the table, urban students had a higher mean of (23.73) and higher standard deviation (14.42) than the mean (18.30) and standard deviation (8.30) for the rural students. These results indicate that students' from urban schools performed better than students from rural schools in WASSCE multiple choice Biology test. Therefore, the null hypothesis one was rejected because there is a significant difference in the students' performance in WASSCE multiple choice Biology test on the basis of school location. 
Hypothesis 2. There is no significant difference in the students' performance in WASSCE multiple choice Biology tests on the basis of gender.

Table 3. T-test Summary of Male and Female Students' Performance in WASSCE Multiple Choice Biology Test

\begin{tabular}{lllllll}
\hline Variable & $\mathbf{N}$ & $\mathbf{X}$ & S.D & DF & Cal. t-value & Sig. of t-value \\
Male & 758 & 19.33 & 9.81 & & & \\
Female & 692 & 25.24 & 15.15 & 1448 & 8.89 & $.000(\mathrm{~S})$ \\
\hline
\end{tabular}

Table 3 reveals that calculated t-value of 8.89 which is significant at 0.05 alpha level. Therefore, the null hypothesis, which says that, there is no significant difference between the performances of male and female secondary school students in the WASSCE multiple choice Biology test, was rejected. As shown in the table above, female students had a higher mean (25.24) and a higher standard deviation (15.15) than the mean (19.33) and standard deviation (9.81) for the male students. These results indicate that, female students performed significantly better than male students in WASSCE multiple choice Biology test.

Hypothesis 3. There is no significant difference in the students' performance in WASSCE multiple choice Biology tests on the basis of school type.

Analysis of Variance (ANOVA) was used by researcher to determine students' performance in WASSCE multiple choice Biology test on the basis of school type i.e mixed schools and single sex schools.

Table 4. ANOVA Summary Table of WASSCE Performance of Students in Multiple Choice Biology Test on the Basis of School Type

\begin{tabular}{llllll}
\hline Source & Sum of Square (SS) & DF & Mean Square (MS) & Cal. F-Value & Sig of F-Value \\
Between Groups & 55107.004 & 2 & 27553.502 & & \\
Within Groups & 188349.2 & 1447 & 130.165 & 211.68 & .000 (S) \\
Total & 243456.2 & 1449 & & & \\
& & & & & \\
\hline
\end{tabular}


Table 4 shows an F-value of 211.681, which is significant at 0.05 alpha level. Therefore, there is a statistically significant difference in WASSCE multiplechoice Biology test on the basis school type. Thus, the null hypothesis three was rejected. The Duncan's Multiple Range Test was employed to confirm the rejection of null hypothesis four.

Table 5. DMRT Showing Students' Performance in WASSCE Multiple Choice Biology Test Based on School Type

\begin{tabular}{lll}
\hline School Nature & Mean Score & Duncan's Grouping \\
\hline Boys only & 15.381 & A \\
Mixed & 20.293 & B \\
Girls only & 37.833 & C \\
\hline
\end{tabular}

Different Duncan letters indicate significant difference in the students' performance in WASSCE multiple choice Biology test on the basis of school type. From the table 5, it can be observed that the students from Girls' schools had highest means score performance (37.833), followed by students from Mixed school with 20.293 mean score and students from Boys' school had a mean score of 15.381. Therefore, the null hypothesis four was rejected because the differences in the mean score of students' performance based on school type were statistically significant at 0.05 alpha levels.

It was found that urban schools performed better in WASSCE multiple choice Biology items with the mean scores of 23.73 than students from rural schools with mean 18.30. The findings of Agnes, Anthony and Julie (2009) indicating that students from rural schools performed better than students from urban schools in Mathematics examination is not in agreement with the findings of this study. The significant difference discovered in the performance of urban and rural students may be because the urban students were exposed to different social amenities and instructional materials, which make then to perform better than students from rural areas where the social amenities and instructional materials may not be available or inadequate.

Female students were found to have performed better in WASSCE multiple choice Biology tests with mean scores of 25.24 respectively than male students with mean scores of 19.33. The findings of this study is against the findings of 
Danmole (1998) which revealed that male students perform better than females in Physics, chemistry and biology but disagreed with that of Bello (1990) who did not find any form of influence being exerted by gender on students' academic performance in the sciences. The findings of Yusuf and Afolabi (2010) showed that gender had no influence on the performance of students in Biology whether they were taught with computer-assisted instruction (CAT) in individualized or co-operative in Biology.

From the findings of this study, students from Girls' schools performed excellently with highest mean scores of 37.833 in WASSCE. This shows that students from Girls' schools performed better than students from Boys' and mixed schools in WAEC SSCE multiple choice Biology tests. Students from mixed schools performed better than students from Boys' schools in WAEC with mean scores of 20.293 .

\section{CONCLUSIONS}

The researcher found from this study that there is significant difference in the WASSCE multiple choice Biology tests on the basis of school location (urban and rural), gender and school type. Urban school students performed better than rural school students. In addition, female students performed better than their male counterpart and Girls' school students performed better than Boys' and mixed schools. School location, gender and school type significantly affect students' performance WASSCE Biology tests.

\section{RECOMMENDATIONS}

Based on the findings, the researcher recommended that:

1. Secondary school administrators and Biology teachers should encourage male and female Biology students' to participate actively during the weekly lessons. Both the male and female students' should be given equal opportunity during the Biology classes to improve their performance in WASSCE.

2. Both the Government and secondary school administrators must pay more attention to all these findings because they can lead to achievement of desired students' performance level in WASSCE multiple-choice Biology tests. 
3. Government and other stakeholders in education should equip rural schools with facilities that are available in urban schools to improve students' performance in WASSCE Biology in rural schools.

\section{ACKNOWLEDGMENTS}

The researcher sincerely acknowledged the co-operation of the Principals, Vice Principals, Biology teachers of the selected schools and the students that participated in this study.

\section{LITERATURE CITED}

Agnes, E.M., Anthony, N.N., \& Julie, E.I. (2009). Analysis of students' performance in junior secondary school mathematics examination in Bayelsa State of Nigeria. Stu. Home Comm.Sci, 3 (2), 131 - 134.

Ahmed, M.A. (2004). Analysis of secondary school biology teachers' ratings of the difficulty level of concepts in nutrition. Unpublished M.Ed Thesis, University of Ilorin, Ilorin.

Ajagun, G.A. (2000). A study of the performance of students in the senior secondary school certificate examination in selected schools in Kano State. Tambori: Kano Journal of Education 6(1): 10-21.

Akpan, B.B. (2008). Nigerian the future of science education. Science Teachers Association of Nigeria (STAN). Ibadan, Nigeria: Oluseyi Press limited.

Alonge, M.F. (2003). Assessment and examination: The pathways to educational development. Inaugural Lecture. University of Ado-Ekiti.

Aremu, S.A. (1999). Games and primary school pupils' achievement in some aspect of geometry. Unpublished Ph.D Thesis, Department of Teacher Education, University of Ibadan, Ibadan.

Bello, G. (1990). Senior secondary school students' knowledge misconceptions and alternative conception of a major biology proposition. Unpublished M.Ed. Thesis, University of Ilorin, Ilorin. 
Bosede, A.F. (2010). Influence of sex and location on relationship between students problems and academic performance. The social science 5(4) 340-345.

Danmole, B.T. (1998). The influence of teacher preparation and use of instructional materials on primary school pupils' performance in integrated science. Ilorin Journal of Education, 12, $56-64$.

Good, C.V. (1973). Dictionary of education. New York: MC Graw-Hill Book Company.

Guarisco, C. (2010). Single-sex schools and gender roles: Barrier or breakthrough?Retrieved from www.luc.edu/law/academics/special/ center/.../Chrissy_Guarisco.pdf

History of JAMB (2004). Retrieved May 12, 2010, from http:// en.wikipedia. org/wiki/west African examinations council.

History of WAEC (2004). Retrieved May 12, 2010, from http://www.waec. nigeria.org/history.htm.

Hornby, A.S. (2000). Oxford Advanced Learners Dictionary of Current English (6th Ed.) Oxford University Press.

Igwe, I.T. (2003). Enriching science education: The place of improvisation in classrom. Science Teachers Association of Nigeria (STAN) 41st Annual Conference Proceedings. 51-53.

Kolawole, E.B. (2005). Test and measurement. Lagos: Bolabay Publications.

Lawal, A. (2001). Evaluation of students' learning outcomes 1: Types and uses of tests. In I.O. Abimbola (Ed.). Fundamental principles and practice of instruction. Ilorin: Belodan (Nig) Enterprises \& Tunde Babs Printers. 
Leder, G.C. (1990). Gender differences in mathematics: An overview. In E. Fennema and G. C. Leder (Eds.), Mathematics and gender (pp. 60- 95). New York, NY: Teachers College Press.

Lee, V. E. \& Marks, H.M. (1990). Sustained effects of the single-sex secondary school experience on attitudes, behaviors, and values in college. Journal of Educational Psychology, 82(3), 578-592.

Lee, V.E., Marks, H.M., \& Byrd, T. (1994). Sexism in single-sex and coeducational independent secondary school classrooms. Sociology of Education 67, 92-120.

Novak, J.D. \& Mosunda, D. (1991). A twelve years longitudinal study of science concept learning. Americana Research Journal, (28), 117-153.

Obioma, G. \& Salawu, M. (2007). The predictive validity of public examinations: A case study of Nigeria. A paper presented at the 33rd Annual Conference of International Association of Educational Assessment (IAEA) held in Baku, Azerbaijan, 16-21.

Okwo, F.A. \& Otunba, S. (2007). Influence of gender and cognitive styles in science achievement in physics essay test. Journal of Science Teachers Association of Nigeria, 42 (1\&2), 85-88.

Olatunji, M.W. (2004). Misconceptions and alternative conceptions of biology concepts held by secondary school students and teachers in Kwara State, Nigeria. Unpublished Ph.D. Thesis, University of Ilorin, Ilorin.

Olutola, A.T. (2015). Item difficulty and discrimination indices of multiple choice biology tests. Liceo Journal of Higher Education Research, 11(1), 16-30.

Onah, E.F. (2011). Influence of sex and school location on students' achievement in agricultural science. African journal of science, Technology and Mathematics Education (AJSTME), 1 (1) 96-102. 
Oni, M.O. (2006). An analysis of difficult biology concepts are perceived by teacher and students in senior secondary schools in Akure, Nigeria. Unpublished M. Ed. Education Thesis, University of Ilorin, Ilorin.

Osunde, A. (2009). Essay and multiple choice tests: Bridging the gap. Workship papers on multiple choice test item writing procedures for academic staff, University of Ilorin, Ilorin, on Monday 4th Monday, 2009. pp. 14-24.

Owoeye, J.S. (2002). The effect of integration of location, facilities and class size on academic achievement of secondary school students in Ekiti State University, Nigeria. Unpublished Ph. D Dissertation, University of Ibadan, Nigeria.

Parker S.P. (1992). Concise encyclopedia of science and technology (Sixth Edition). New York; MC Graw-Hill, Companies P 252.

Somoye, B.I. (2002). "Hints on examination practice". A paper presented at the workshop on examination administration at AOCOED, Oto-Ijanikin, Lagos.

Spence, D.J. (2004). Engagement with mathematics courseware in traditional and online learning environments: Relationship to motivation, achievement, gender and gender orientation. Unpublished Ph.D Dissertation, Emory University .Retrieved March 17, 2007, from http://www.des.emory.edu/mfp/Spence Dissertation 2004.pdf.

Streitmatter, J. (2002). Perceptions of a single-sex class experience: Females and males see it differently. In A. Datnow \& L. Hubbard (Eds.), Gender in policy and practice: Perspectives on single-sex and coeducational schooling. New York: Routledge. pp. 212-226.

Taber, K.S. (1992). Girls interactions with teachers in mixed physics classes: Results of classroom observation. International Journal of Science Education, 14, 163-180. 
Unoroh, E.M. (2004). Level of difficulty of chemistry topics as perceived by senior secondary school teachers and students in Ekiti State. Unpublished M. Ed. Science Education Thesis, Department of Science Education, University of Ilorin, Ilorin.

WAEC (2007). The west african senior school certificate examination. The chief examiners' reports for Nigeria.

WAEC (2001). Performance of candidates in the May/June 2000 SSCE in Science Subjects. Ilorin; WAEC Report.

WAEC (2007). History of west african examinations council. Retrieved 20/05/2011 at http// www: waecnigeria.org. history.htm

WAEC Diary (2004). Brief history of the council. Lagos: Academy Press PLC.

WAEC (2012). Year 2012 21st WAEC state committee meeting agenda papers for Taraba State. West African Examination Council.

Yusuf, M.O. \& Afolabi, A.O. (2010). Effects of computer assisted instruction (CAI) on secondary school students' performance in biology. The Turkish Online Journal of Educational Technology, 9, (1), 62 - 69 . 